\title{
Capital structure of Chinese listed SMEs: an agency theory perspective
}

\author{
Wei Huang • Agyenim Boateng • \\ Alexander Newman
}

Accepted: 23 March 2016/Published online: 2 May 2016

(C) The Author(s) 2016. This article is published with open access at Springerlink.com

\begin{abstract}
Prior work examining the antecedents of capital structure for small and medium-sized enterprises in emerging markets is limited. This paper sheds light on how the corporate governance mechanisms adopted by firms on the newly established Growth Enterprise Market (GEM) in China influence their use of debt. We find that the financial leverage of GEM firms is positively influenced by executives' shareholding and their excess cash compensation. Ownership concentration appears to reduce leverage, whereas the percentage of tradable shares increases leverage. In contrast, institutional investors' shareholding does not influence the level of debt. Traditional factors such as tax and operating cash flow are insignificant in explaining the debt levels among GEM firms.
\end{abstract}

\section{W. Huang $(\bowtie)$}

Nottingham University Business School China, University of Nottingham Ningbo China, 199 Taikang East Road,

Ningbo, China

e-mail: Wei.Huang@nottingham.edu.cn

A. Boateng

Department of Law, Economics, Accountancy and Risk, Glasgow Caledonian University, Glasgow, UK e-mail: Agyenim.Boateng@gcu.ac.uk

\section{A. Newman}

Department of Management, Deakin University,

Melbourne, VIC, Australia

e-mail: A.Newman@deakin.edu.au
Keywords Capital structure $\cdot$ Executive compensation - Ownership structure $\cdot$ SMEs $\cdot$ China

JEL Classifications $\quad \mathrm{G} 32 \cdot \mathrm{L} 26$

\section{Introduction}

Small and medium-sized enterprise (SME) financing is a topic of significant research interest to both academics and policy makers. This is because SMEs play a vital role in providing employment and sustaining economic growth in both developed and emerging economies such as China (Du et al. 2015). For example, according to the Chinese National Bureau of Statistics, SMEs account for about $99 \%$ of the total number of firms in China and contribute about $60 \%$ of the country's total gross industrial output. Yet prior studies have documented the difficulty of accessing finance as one of the biggest constraints that impedes the growth SMEs around the globe (Beck and Demirguc-Kunt 2006; Beck et al. 2008). Challenges faced by SMEs in accessing external financing are even more pronounced in emerging economies such as China due to a weak institutional environment, which has resulted in the limited development of debt and equity markets for small enterprises (Newman et al. 2012). A recent study by Elston et al. (2016) suggests that informal capital in the forms of personal savings, family funding, and 
household income is still predominantly used over formal capital sources in the start-up phase, underscoring the slow transition in China from an emerging to a modern economy.

In order to improve access to external finance for growth SMEs, China has recently established a Growth Enterprises Market (GEM) Board in 2009. This board is similar to the NASDAQ in the United States, AIM in the UK, EASDAQ in Europe, and SESDAQ in Singapore. According to Lee et al. (2004), the main reason for the establishment of the GEM Board is to provide a mechanism for SMEs, most of which are high-technology related, to raise funds and therefore have the potential for high growth. The establishment of the GEM is significant because it increases access to external equity and improves the governance structure of SMEs. For example, listing shares on the GEM Board requires firms to reduce the level of insider ownership, and increases levels of ownership by outside investors such as mutual funds and minority shareholders, thereby leading to a more diffused ownership structure and better corporate governance, which should in turn improve access to external financing and enhance long-term performance.

Recently, a cross-country study by Nofsinger and Wang (2011) pointed out that there are information asymmetries and moral hazard problems inherent in the funding of SMEs. Although there is a growing stream of research investigating capital structure antecedents for larger listed firms and non-listed SMEs in China and other emerging markets (Chen 2004; Du et al. 2015; Huang and Song 2006; Li et al. 2009; Liu and Tian 2012; Newman et al. 2012; Köksal and Orman 2015), and listed SMEs in more advanced economies (Dasilas and Papasyriopoulos 2015), prior work has not examined the factors that drive the capital structure of growth SMEs listed on SME boards in emerging economies such as the GEM Board. This group of SMEs is likely to differ from larger listed enterprises and non-listed SMEs in a number of ways. First, in comparison with larger listed enterprises, which are predominantly former stateowned enterprises, there is likely to be a higher level of ownership concentration in SMEs on the GEM Board, given that most of these firms originated as familyowned businesses, in which the founder and their family members continue to retain a significant shareholding and involvement in the business (Ding et al. 2010). As a result, this provides a unique governance context compared to larger listed enterprises, where state ownership and control appear much more pervasive. Second, compared to non-listed SMEs, the involvement of shareholders from outside the founding family ensures higher levels of transparency in firms listed on the GEM Board. Typically, there is better corporate governance in the form of monitoring of management by outside shareholders than for non-listed firms, due to stock listing requirements (Ding et al. 2010).

Given these unique differences between listed SMEs, and both larger listed firms and non-listed SMEs, the present study utilized data from the Chinese GEM Board to examine the influence of corporate governance mechanisms on the capital structure of SMEs. In doing so, it makes a significant contribution by examining whether the provision of managerial incentives to align the interest of management and shareholders, and outside involvement in ownership, influences the capital structure of growth SMEs. Although researchers have begun to examine the determinants of SMEs capital structure based on traditional theories of capital structure such as the static tradeoff and pecking-order theories, prior work has neglected the important role played by corporate governance in influencing the use of debt (Dasilas and Papasyriopoulos 2015), especially in emerging economies. This results from the fact that prior work has typically focused on non-listed SMEs, where corporate governance is weak and outside ownership is nonexistent (Du et al. 2015). Through accessing recent data on growth SMEs, we are now able to examine the role played by these mechanisms in facilitating an improved access to external capital in the emerging economy context, where GEM Boards have recently been established. More specifically, we utilize agency theory (Jensen and Meckling 1976; Jensen 1986) to explain how corporate governance influences access to external debt. Agency theory suggests that such effective outside ownership and incentive structures for the firm's management will make the firm more attractive to outside investors. Yet its relevance to explain how such mechanisms influence SME's use of external financing in emerging economies has yet to be investigated. Using a large dataset consisting of 384 Chinese listed SMEs on the GEM Board in the period from 2009 to 2013, we employed system-GMM to examine the effects of corporate governance on capital 
structure. Previous studies in the Chinese context have used different statistical analysis encompassing pooled OLS, fixed- and random-effect models (Chen 2004; Huang and Song 2006), which assume that capital structure decisions are static. However, a more realistic assumption would be that managers adjust their financing mix due to internal changes or external shocks (see Antoniou et al. 2008; Hui et al. 2006). To account for such considerations and overcome the problem of endogeneity, we use the dynamic estimation technique to model a firm's capital structure choices. Our research also has important implications for practitioners and academics in emerging economies. It will assist them to understand how corporate governance mechanisms influence the growth SMEs' use of external debt. This is important as access to adequate debt financing has been shown to improve performance outcomes among SMEs (Watson 2006; Berger and Udell 1998).

The rest of the paper is structured as follows. Section 2 presents the institutional background of the Chinese GEM Board. Section 3 reviews the literature and develops our hypotheses. Section 4 describes our data and methodology. Section 5 reports our results, followed by policy implications in Sect. 6. Section 7 concludes.

\section{The Chinese Growth Enterprises Market Board}

On October 30, 2009, the Chinese Growth Enterprises Market (GEM) Board (Chuang Ye Ban) opened trading in Shenzhen, and the first 28 firms launched their IPOs after a prolonged period of preparation. This second board of the stock exchange was established to provide smaller, fast-growing, technological, and typically more "entrepreneurial" firms opportunities for stock market public listings in a separate venue with lower listing requirements compared to the two main stock markets in Shanghai and Shenzhen. The GEM Board is similar to NASDAQ, which was originally comprised of mainly high-tech and pharmaceutical companies that had a need for external financing, but did not fulfill the requirements to be listed on the main board New York Stock Exchange (Lee et al. 2004). By June 2013, around 350 listed firms were trading on the Chinese GEM Board compared to over 2,100 listed firms on the main board. Among the firms listed on the GEM, 77 are from the telecommunication industry and 229 are from the high-tech or technology-intensive manufacturing industry. Most of them are high-growth and ownermanaged firms, still run by their founders (Ding et al. 2010).

Compared to the GEM Board, the main board listing rules in China require more strict compliance as regards pre-IPO size, business history, and profitability. Specifically, for firms to seek listing, the GEM Board requires a minimum pre-IPO total firm equity capital of 20 million Chinese Yuan, 2 years of business history, and positive net profits for the most recent accounting year. In contrast, the main board requires a minimum pre-IPO total equity of 30 million, 3 years of business history with consecutive positive net profits that accumulate to more than 30 million Chinese Yuan, accumulated net operating cash flows in the recent 3 accounting years to exceed 50 million Chinese Yuan, or the accumulated total revenue to exceed 300 million Chinese Yuan. As a result of relatively less stringent disclosure requirements, there are somewhat higher levels of information asymmetry among firms on the GEM Board than among the firms on the main board.

The firms listed on the GEM Board exhibit different ownership and governance features compared to firms on the main board. Almost all firms on the GEM Board are under the control of private investors or firms, whereas the majority of firms on the main board are under control of the government at the central or local level (Chen et al. 2009; Li et al. 2011). Most of the main board listed firms are carve-outs or spin-offs from existing state-owned enterprises (SOEs) (Jiang et al. 2010), whereas GEM firms are typically entrepreneurial firms under the control of their founders. As of the end of 2013, of 397 firms listed on the GEM Board, only 13 firms were under government control. In comparison, over half of the firms listed on the main board exchanges were under government control. In GEM firms, founding entrepreneurs and senior executives typically retain a significant percentage of shares on stock market flotation, which can potentially reduce principal-agent conflicts (Jensen and Meckling 1976). Typically, the percentage of stock owned by executives and board members is much lower for firms listed on the main board in China, especially for government-controlled firms (Chen et al. 2009; Jiang et al. 2010). 


\section{Literature review and hypotheses development}

\subsection{Agency theory and capital structure}

A large body of literature in corporate governance and capital structure research utilized agency theory to argue that the conflict of interest between managers and shareholders of a firm affects corporate policy choices such as capital structure decisions (Berger et al. 1997). The overall thrust of agency theory is that managers are self-serving and may have goals that diverge from those of owners, which, if not monitored, may lead them to engage in actions that come at the expense of owner wealth maximization (Jensen and Meckling 1976). Leverage decisions are among the important corporate policy choices made by managers that are prone to agency problems, as the level of leverage affects the riskiness of the firm and may lead the management to be displaced in the event of takeover (Jensen and Meckling 1976). Although recent work by Dasilas and Papasyriopoulos (2015) and Haque et al. (2011) has examined the effects of corporate governance on capital structure decisions in Greece and Bangladesh, the subject remains underresearched in the context of emerging economies. This study is the first attempt to examine the effects of corporate governance mechanisms on the leverage decisions adopted by SMEs listed on the Chinese GEM Board. We now briefly review the extant literature linking corporate governance mechanisms to leverage decisions from a managerial structural power standpoint, highlighting the role played by information asymmetry and monitoring, to ground our hypothesis development.

Structural power, which is based on formal organization structure and hierarchical authority, constitutes the driving force behind the evolution of organizations (Hambrick and Mason 1984; Finkelstein 1992). This stream of literature contends that strong managerial power exacerbates agency problems, allows management to make suboptimal investment decisions, and strategically increases their power to derive benefits from control of their companies (Shleifer and Vishny 1989; Liu and Jiraporn 2010). Moreover, as dominance of the managerial team strengthens, the firm experiences higher information asymmetry, making it more difficult for shareholders and bondholders to monitor managers' actions. In short, dominance of management leads to managerial entrenchment and reduces reporting transparency. However, previous studies examining the relationship between managerial entrenchment and leverage decisions have produced mixed results (see Stulz 1990; Berger et al. 1997; Fama 1980). For example, Stulz (1990) and Harris and Raviv (1988) present evidence to support the view that entrenchment motives may lead managers to increase leverage beyond the optimal point, in order to increase their control and reduce pressure from external shareholders. Conversely, Fama (1980) notes that entrenched managers may prefer less leverage than is optimal because of their preference for lower firm risk to protect their underdiversified human capital. In conclusion, it is acknowledged that the prevailing view in the literature is that self-serving managers do not make capital structure decisions that maximize shareholder wealth.

Scholars therefore highlight the importance of good internal corporate governance and monitoring mechanisms to alleviate the agency problem. For example, Bhojraj and Sengupta (2003) and Gompers et al. (2003) suggest that good corporate governance systems reduce agency costs and the cost of debt financing. Bhojraj and Sengupta (2003) argue that effective corporate governance results in an efficient utilization of resources by managers, reduces default risk, and thereby lowers the cost of debt. More importantly, effective governance reduces information asymmetry by ensuring the release of credible financial information (Ajinya et al. 2005) and restrains managers from using private information for their own interests at the expense of shareholders (Jensen and Meckling 1976; Myers and Majluf 1984). A study by Dasilas and Papasyriopoulos (2015) established that corporate governance structures and credit ratings play a significant role in the capital structure decisions of listed firms in Greece. However, they also found that, in terms of SMEs, the influence of corporate governance variables on capital structure appears to be less pronounced than for larger firms. Dasilas and Papasyriopoulos (2015) attributed these results to the active involvement of owners in the management of SMEs, which lessens the need for monitoring mechanisms. The studies of Wen et al. (2002), Berger et al. (1997) have rendered some support for the association between corporate governance and capital structure decisions, but it should be noted that the results obtained thus far have been mixed. Given the relatively weak corporate governance systems in 
emerging countries such as China, high ownership concentration (La Porta et al. 1999), and the less stringent requirements for listed firms, it is important to apply the agency cost perspective in a different context, i.e., growth SMEs on the GEM Board in China, to provide more insight into how governance factors such as ownership, compensation, and tradable shares affect leverage decisions. The following section presents a number of hypotheses that reflect how managerial power and monitoring mechanisms may influence capital structure decisions.

\subsection{Hypotheses development}

\subsubsection{Managerial shareholding and capital structure}

Past empirical research indicates that a firm's corporate financing policy is strongly influenced by the agency problems it faces (Berger et al. 1997; Jensen and Meckling 1976; Myers and Majluf 1984). It is argued that conflict of interests over financing policy between shareholders and managers arise because managers may pursue goals that are attractive to them. For example, the use of debt reduces the need for external equity. Consequently, in their quest to maintain the level of their shareholding and avoid the dilution of managerial shareholding and control, managers would typically issue more debt than equity. This is particularly relevant to the Chinese GEM firms that are typically founder-controlled. A number of studies (e.g., Stulz 1990; Berger et al. 1997; Kim and Sorensen 2006) find a positive relationship between managerial shareholding and a firm's debt ratio. Consistent with earlier studies on larger listed firms, we expect the proportion of managerial shareholding to be positively associated with the SME debt ratio. This leads us to the following hypothesis.

H1: The executives' shareholding is positively related to SMEs' use of debt financing.

\subsubsection{Cash compensation and capital structure}

Prior literature provides empirical evidence of a strong causal relationship between the compensation structure and debt policy of a firm (see Coles et al. 2006). As cash compensation is immediate and certain, and not subject to volatility compared to stock-based compensation, it may be argued that cash compensation provides executives with an incentive to engage in riskier decisions and implement more aggressive debt policy with no consequences on their long-term returns. Given that management power theory suggests that excessive cash compensation is a proxy of managerial structural power (Chen et al. 2011; Chung et al. 2015), and debt enables managers to control more resources, we expect a positive relationship between excess cash compensation and the debt ratio in a firm's capital structure. This argument is particularly the case in emerging economies where the corporate governance system is weak, and managers with control rights have greater incentive to expand their control of resources in order to tunnel resources for private benefits (Liu and Tian 2012; Qian and Yeung 2015). The above reasoning leads to the following hypothesis:

H2 Executive excess cash compensation is positively related to SMEs' use of debt financing.

\subsubsection{Ownership concentration and capital structure}

Prior research has shown that the ownership structure of a firm has a palpable impact on its financing decisions (Berger and Udell 2006). One dimension of ownership structure that may affect capital structure choice is ownership concentration. It is argued that ownership concentration provides large shareholders with control rights and incentives to pursue their own personal interests by transferring or tunneling resources out of the firm (Lin et al. 2012). Recent studies by Liu and Tian (2012) and Qian and Yeung (2015) report that excess control rights associated with concentrated ownership and inefficient state-owned banks in China allow firms to tunnel excess leverage out of the firm. Researchers such as Faccio et al. (2010) and Claessens et al. (2002) also find that controlling shareholders' use leverages without diluting their control over the firm to enable tunneling. This type of agency problem is usually referred to as the type II agency conflict or principal-principal conflict. Further, considering that the firms in the GEM Board are typically controlled by dominant shareholders and founding entrepreneurs, we expect ownership concentration to be positively associated with leverage. This is because leverage places more resources at the 
disposal of the controlling shareholders in an environment where corporate governance is weak (Liu and Tian 2012; Qian and Yeung 2015), thereby enabling tunneling activities by the large shareholders. The above discussion leads to the following hypothesis:

H3 Shareholding concentration is positively related to SMEs' use of debt financing.

\subsubsection{Tradable shares and capital structure}

Before the split-share structure reforms, Chinese capital markets classified shares into tradable shares and non-tradable shares, where non-tradable shares were not publicly traded. The presence of non-tradable shares hindered an efficient functioning of the stock market, and the Chinese government has carried out a split-share structure reforms since 2005 to gradually transition from the non-tradable shares to tradable shares over an extended period of time in order to reduce the impact of non-tradable shares on stock prices (Li et al. 2011). This reform has improved asset valuation of firms and reduced the information asymmetry between borrowers and lenders, as potential lenders now have a fair value of the firm's assets with which to make leverage decisions. Higher percentage of tradable shares also attract more diverse shareholder base and increase tradable equity capitalization. Recent work suggests that the split-share structure reform has led to investor wealth gains from risk sharing ( $\mathrm{Li}$ et al. 2011). This suggests that the conversion of non-tradeable shares to tradeable shares may reduce credit risk and liquidity risk, allowing firms to borrow more. This leads us to the following hypothesis:

H4 The percentage of tradable shares as a proportion of total common shares is positively related to SMEs' use of debt financing.

\subsubsection{Institutional investor shareholding and capital structure}

Nofsinger and Wang (2011) show that institutional investors rely on the experience of entrepreneurs and the quality of investor protection to reduce moral hazard among start-up firms. In addition, Yuan et al. (2009) report that mutual fund organizations in China often help their portfolio companies prepare financial forecasts, standardize their operations, and strengthen their company image in the capital markets. In support of such an assertion, Yuan et al. (2008) find that the equity ownership by mutual funds has a positive effect on firm performance. In particular, Firth et al. (2010) also illustrate that mutual funds ownership increased tradable shareholders' bargaining power against state shareholders during China's split-share structure reform. This suggests that the recent regulatory efforts in China to promote mutual funds as a corporate governance mechanism that pools the diffuse minority interests of individual shareholders who are prone to free-rider problems have met with some degree of success. The improved information environment and quality of external monitoring result from the involvement of mutual funds in ownership may enhance creditability and allow firms to borrow more. Active trading by the mutual funds is also expected to lead to more efficient pricing and higher sensitivity to marketwide information (Chuang and Lee 2011). This leads us to the following hypothesis:

H5 The percentage of institutional investor's shareholding is positively related to SMEs' use of debt financing.

\section{Data and methods}

We collected our data from the Chinese Stock Market and Accounting Research (CSMAR) database for the financial years 2009-2013. Our original sample includes all 397 listed firms on the GEM Board at the end of year 2013. We excluded 13 firms whose controlling shareholder is the State-owned Assets Supervision and Administration Commission of the State Council (SASAC) as these firms have different governance structures, share types, access to finance, and risk profiles compared to firms controlled by private investors (for a review, see Firth et al. (2009) and Qian and Yeung (2015)). We note that all the remaining firms are controlled by private investors and have $100 \%$ common equity issued as A-shares, in which on average $38.6 \%$ are tradable during the sample period. We further drop observations with negative equity book value resulting in a final sample of 1214 observations.

We adopt both the market value-based financial leverage ratio and the book value-based debt-to-assets ratio as proxies for capital structure. Figures 1 and 2 


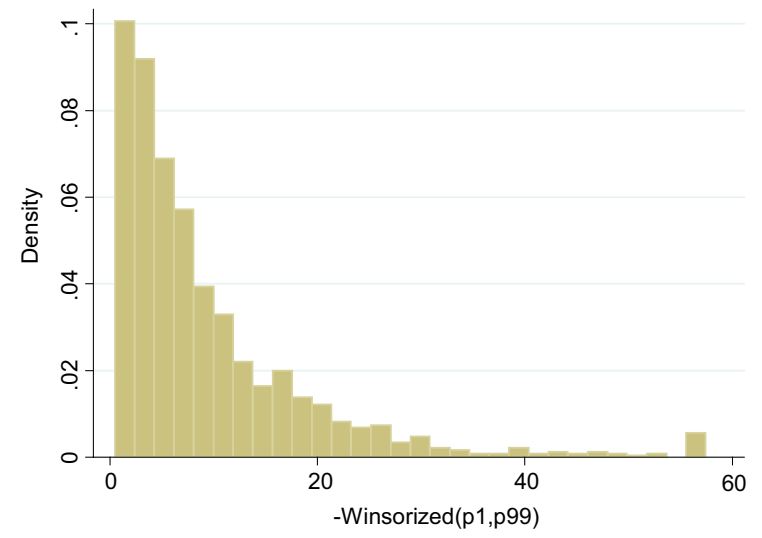

Fig. 1 Histogram of market value financial leverage $=100 *$ book value of debt/(book value of debt + market capitalization)

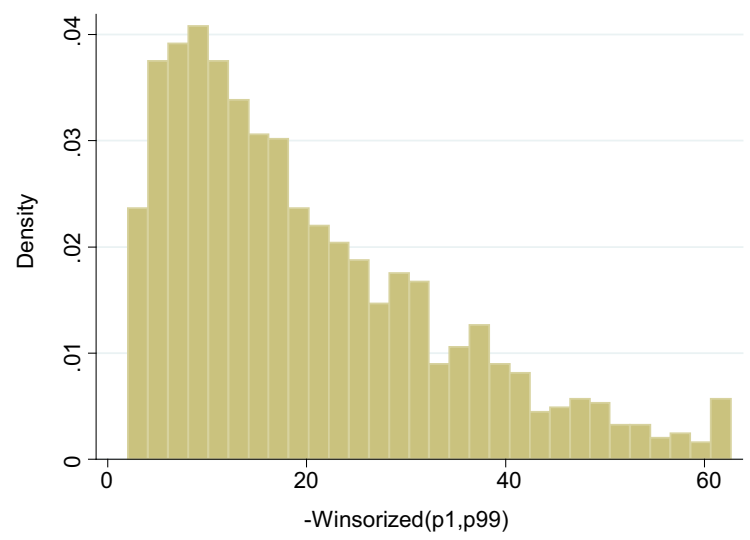

Fig. 2 Histogram of book value debt-to-assets percentage ratio

exhibit the distribution of these two variables across the sample.

To adjust for non-normal distributions, we use the log-transformed capital structure variables $\log (\mathrm{LEV})$ and $\log (\mathrm{DE})$, denoting the market value- and book value-based ratios, respectively, in our empirical analysis. Prior studies show that corporate governance choices are endogenous (for a review, see Wintoki et al. (2012)). Following prior studies on capital structure such as Antoniou et al. (2008) and Guney et al. (2011), we adopt the two-step dynamic panel System-GMM (Arellano and Bover 1995; Blundell and Bond 1998) with Windmeijer (2005) bias-corrected robust standard errors to simultaneously account for the endogeneity of ownership, governance, and leverage. Our model includes firm fixed effects $\alpha_{i}$ and disturbance term $\varepsilon_{i t}$ as follows:
$\mathrm{CS}_{i t}=\alpha_{i}+\eta \mathrm{CS}_{i t-1}+\beta \mathrm{CG}_{i t}+\gamma \mathrm{X}_{i t}+\varepsilon_{i t}$

We first difference all the variables to control for unobserved heterogeneity $\alpha_{i}$ and eliminate potential omitted variable bias and use lagged values of the governance variables, ownership variables, and other firm characteristics as instruments for estimation. We test for autocorrelation of the second-order AR(2) and conduct the Hansen test of overidentification to ensure the validity of our methods.

The dependent variable $\mathrm{CS}_{\text {it }}$ refers to market valuebased financial leverage ratio $\log (\mathrm{LEV})$ and book value-based financial leverage ratio $\log (\mathrm{DA})$. The independent variables $\mathrm{CG}_{\mathrm{it}}$ refer to the corporate governance variables. First, we measure managerial power (Chen et al. 2011; Chung et al. 2015) using the $\log$ of executives' total shareholding $\log (\mathrm{EXSH})$ and the excessive log cash compensation to top executives EX.Log(EXP). We estimate size- and industry-adjusted excessive executive compensation as a proxy for managerial power and agency cost. ${ }^{1}$ Other $\mathrm{CG}_{\mathrm{it}}$ variables are $\mathrm{CON}$, shareholding concentration as the total percentage shareholding of top 10 shareholders; TRADE, the percentage of tradable A-shares in total number of common shares ${ }^{2}$; INS, the percentage of institutional investors' shareholding. In line with previous research, $\mathrm{X}_{\mathrm{it}}$ denotes a group of control variables including $\log (\mathrm{MC})$, the $\log$ of total market capitalization in millions of Chinese Yuan as a proxy for size $^{3}$; TAX, the percentage of corporate tax rate; $\mathrm{ROA}$, the return on asset; $\mathrm{CF} / \mathrm{Sales}$, the net operating cash flow-to-sales ratio; BIND, the percentage of board members who are independent; CEOD, a dummy that

\footnotetext{
$\overline{1}$ We first regress the log of the average of top 3 executives' cash compensation in 1,000 s of Chinese Yuan $\log ($ E.P) against the $\log$ of firm market capitalization and a set of industry dummies. EX.Log(E.P) is then calculated as the actual $\log ($ E.P) value minus the regression predicted value. The above calculation (excess compensation) reflects managerial power, which may lead to a pursuit self-interests and exacerbate agency problems (see Chen et al. 2011; Chung et al. 2015).

2 The tradable shares do not include the restricted A-shares or B-shares which are locked up after the split-share structure reform until trading restrictions are further removed on these restricted shares over the ensuing years.

${ }^{3}$ We also use the log of sales as an alternative proxy for firm size to check for robustness, and the results not reported to conserve space appear similar to the findings reported.
} 
equals to 1 if the CEO and the Chair of the board are the same persons and 0 if not. "Appendix" provides more detailed descriptions of variable measurement and theory predictions.

Table 1 shows the summary statistics of our sample. All variables are winsorized at 1 and $99 \%$ to control for outliers. The average book value debt ratio is around $20 \%$ of their total assets. The average market value debt ratio is $9.44 \%$ of the firm value. This is consistent with previous research, which suggests that Chinese SMEs have lower levels of long-term debt than firms from more developed economies (Newman et al. 2012).

We also report a pairwise correlation matrix of the variables in Table 2 to show basic univariate relationships among the sample variables. We notice that the leverage ratios are positively correlated with executives' shareholding and cash compensation, and tradable shares percentage, and negatively correlated with the shareholding concentration ratio. The relationship between institutional shareholding and leverage appears negative for the market value-based leverage ratio and positive for the book value-based leverage ratio.

\section{Results}

The effects of corporate governance variables on the capital structure decisions of GEM firms are reported in Tables 3, 4, and 5. The second-order serial correlation tests $\mathrm{AR}(2)$ and Hansen tests suggest that our GMM models are valid. In particular, the second-order autocorrelation is insignificant. ${ }^{4}$ The null hypothesis for Hansen tests that our instruments are valid cannot be rejected in all specifications.

\subsection{Managerial shareholding, cash compensation, and debt ratio}

Table 3 reports the impact of executives' shareholding and excess cash compensation on firms' debt ratios. Hence, the analysis focuses on type 1 agency conflict, namely principal-agent conflict. The coefficients on $\log (\mathrm{EXSH})$ and EX.Log(EXP) are positive and significant, indicating that executives' shareholding

\footnotetext{
${ }^{4}$ The first-order autocorrelation is significant as expected due to first differencing.
}

Table 1 Summary statistics

\begin{tabular}{|c|c|c|c|c|c|}
\hline Variable & Obs. & Mean & SD & Min & Max \\
\hline LEV & 1214 & 9.44 & 9.91 & 0.47 & 57.46 \\
\hline DA & 1214 & 19.97 & 13.72 & 2.03 & 62.63 \\
\hline $\log (\mathrm{LEV})$ & 1214 & 1.78 & 1.00 & -0.75 & 4.05 \\
\hline $\log (\mathrm{DA})$ & 1214 & 2.74 & 0.76 & 0.71 & 4.14 \\
\hline STLEV & 1214 & 8.48 & 9.20 & 0.40 & 55.50 \\
\hline LTLEV & 1214 & 0.93 & 1.66 & 0.00 & 9.94 \\
\hline Log(STLEV) & 1214 & 1.65 & 1.02 & -0.91 & 4.02 \\
\hline Log(LTLEV) & 1000 & -0.94 & 1.69 & -6.84 & 2.44 \\
\hline LTD & 1214 & 10.61 & 13.82 & 0.00 & 78.46 \\
\hline $\log (\mathrm{EXSH})$ & 1055 & 2.70 & 1.62 & -7.46 & 6.37 \\
\hline $\log (\mathrm{EXP})$ & 1200 & 12.76 & 0.56 & 11.47 & 14.34 \\
\hline $\mathrm{CON}$ & 1204 & 68.00 & 9.97 & 40.02 & 92.99 \\
\hline HHI & 1200 & 0.16 & 0.09 & 0.03 & 0.41 \\
\hline TRADE & 1212 & 38.60 & 18.42 & 0.00 & 100.00 \\
\hline INS & 1162 & 23.86 & 19.35 & 0.07 & 74.50 \\
\hline $\log (\mathrm{MC})$ & 1214 & 7.78 & 0.82 & 4.62 & 9.83 \\
\hline TAX & 1210 & 15.04 & 2.88 & 0.00 & 25.00 \\
\hline ROA & 1214 & 8.20 & 5.59 & -7.41 & 27.07 \\
\hline $\mathrm{CF} / \mathrm{Sales}$ & 1214 & 7.01 & 17.43 & -38.28 & 59.58 \\
\hline BIND & 1197 & 37.47 & 5.40 & 25.00 & 60.00 \\
\hline CEOD & 1197 & 0.53 & 0.50 & 0.00 & 1.00 \\
\hline
\end{tabular}

Variables are winsorized at 1 and $99 \%$ to control for outliers

Variable definitions: LEV is the market value-based financial leverage ratio; DA is the book value-based financial leverage ratio; $\log (\mathrm{LEV})$ is the $\log$ of financial leverage ratio; $\log (\mathrm{DA})$ is the log of debt-to-assets ratio; STLEV is the market valuebased short-term debt ratio; LTLEV is the market value-based long-term debt ratio; $\log ($ STLEV) and $\log ($ LTLEV) are the log-transformed short-term and long-term debt ratio. LTD is the percentage of long-term debt in total debt; $\log (\mathrm{EXSH})$ is the $\log$ of executives' total number of shareholdings. $\log (\mathrm{EXP})$ is the $\log$ of average of top 3 executives' cash compensation in $1,000 \mathrm{~s}$ of Chinese Yuan. $\mathrm{CON}$ is the shareholding concentration ratio calculated as the total percentage shareholding of top 10 shareholders. HHI is the Herfindahl-Hirschman index (HHI), which is the sum of the squared values of the percentage ownership of each of the top ten shareholders. Trade is the percentage of tradable A-shares in total number of common shares; INS is the percentage of institutional investors' shareholding; $\log (\mathrm{MC})$ is the $\log$ of total market capitalization in millions of Chinese Yuan as a proxy for size; TAX is the percentage corporate tax rate; ROA is the return on asset; $\mathrm{CF} / \mathrm{Sales}$ is the net operating cash flowto-sales ratio; BIND is the percentage of board members who are independent; CEOD is a dummy that equals to 1 if the CEO and the Chair of the board are the same persons or 0 if not

and cash compensation increase the financial leverage of GEM firms, thereby supporting Hypotheses 1 and 2 . We note that the lagged leverage ratios are positively 


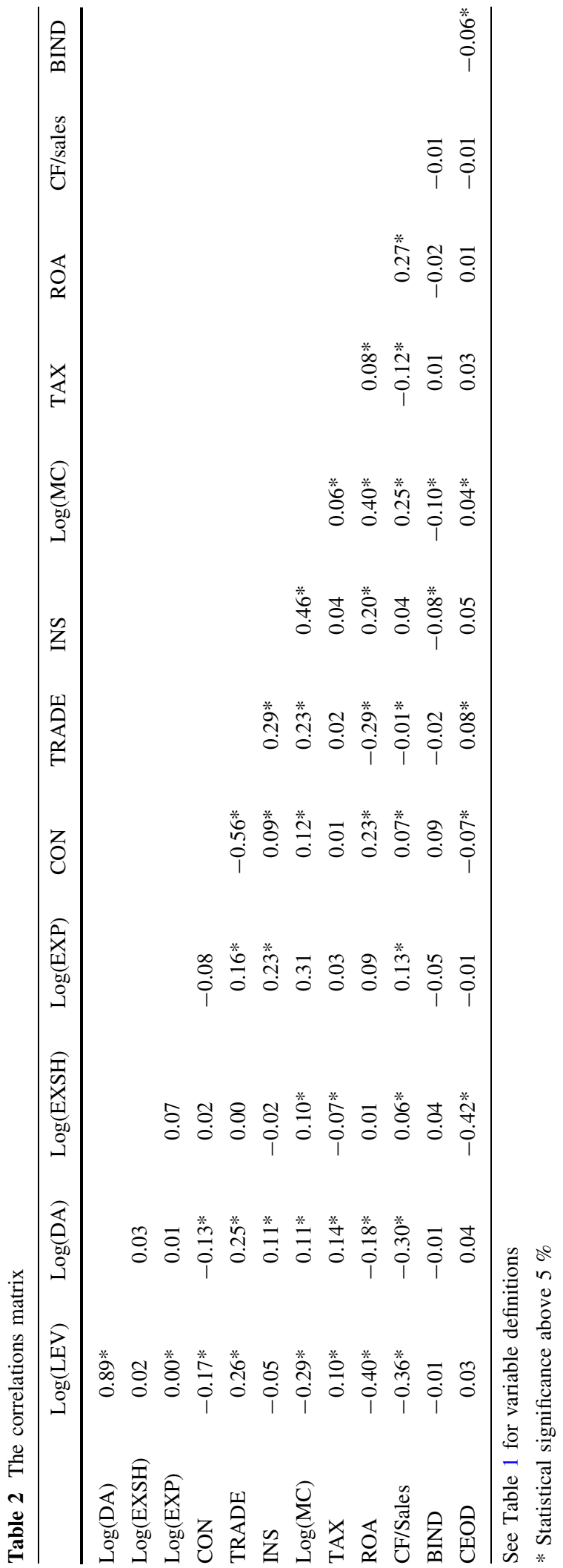

and significantly related to the current period leverage ratios. The coefficients indicate that the persistence of capital structure is much lower when debt is measured at market value, suggesting that the GEM firms are more likely to use dynamic capital structures.

Our findings provide important insights on how corporate governance influences the use of external debt by firms on the GEM market. First, in line with the Hypothesis 1, our findings suggest that the management shareholding in Chinese SMEs results in the greater use of debt finance by SMEs in China. As the use of debt reduces the need for external equity, it provides SME managers with the ability to issue more debt without diluting ownership and control to pursue their own private interest. One plausible explanation for our findings is managerial entrenchment motives, which may cause managers to increase leverage, in order to inflate the voting power of their equity stakes, reduce the possibility of takeover attempts, and retain their jobs (Harris and Raviv 1988). Consequently, the use of managerial shareholding as a means to mitigate conflict of interests in SMEs in China appears ineffective. These findings are in line with those from earlier studies (Stulz 1990; Berger et al. 1997; Kim and Sorensen 2006), which find a positive relationship between managerial shareholding and a firm's debt ratio. Regarding the effects of excess cash compensation on leverage decisions, our results indicate that firms with greater excess cash compensation for firm management have higher levels of external debt and hence Hypothesis 2 is supported. The findings are in line with the management power theory (Chen et al. 2011; Chung et al. 2015), which suggests that debt enables managers to control more resources to engage in rent seeking in an environment where corporate governance is weak.

\subsection{Ownership and debt ratio}

Table 4 shows the effect of ownership structure on firms' debt ratios. Hence, we focus on type 2 agency conflict, namely principal-principal conflict between firm controlling shareholders and minority shareholders. Contrary to Hypothesis 3, ownership concentration exerts a negative and significant influence on firms' debt ratios. In line with Hypothesis 4, the percentage of tradable shares appears to be positively related to the level of debt. Finally, contrary to 
Table 3 Executives' influence on capital structure

\begin{tabular}{|c|c|c|c|c|}
\hline $\begin{array}{l}\text { Model } \\
\text { Dep. Var. }\end{array}$ & $\begin{array}{l}\text { (1) } \\
\log (\mathrm{LEV})\end{array}$ & $\begin{array}{l}\text { (2) } \\
\log (\mathrm{DA})\end{array}$ & $\begin{array}{l}\text { (3) } \\
\log (\mathrm{LEV})\end{array}$ & $\begin{array}{l}(4) \\
\log (\mathrm{DA})\end{array}$ \\
\hline L.Log(LEV) & $0.353 * * *(5.66)$ & & $0.253 * * *(2.97)$ & \\
\hline L.Log(DA) & & $0.809 * * *(8.69)$ & & $0.578 * * *(4.79)$ \\
\hline $\log (\mathrm{EXSH})$ & $0.337 * * *(2.58)$ & $0.215 * *(2.05)$ & & \\
\hline EX.Log(EXP) & & & $1.392 * * *(3.24)$ & $0.818 * *(2.52)$ \\
\hline $\log (\mathrm{MC})$ & $-0.635^{* * *}(-9.06)$ & $0.048(0.69)$ & $-0.400 * * *(-4.54)$ & $0.265 * * *(3.38)$ \\
\hline TAX & $0.012(0.63)$ & $0.007(0.37)$ & $-0.004(-0.20)$ & $0.003(0.16)$ \\
\hline ROA & $-0.032 * * *(-2.92)$ & $-0.023 * * *(-2.93)$ & $-0.045^{* * *}(-3.81)$ & $-0.030 * * *(-3.49)$ \\
\hline CF/Sales & $-0.001(-0.50)$ & $0.003(1.47)$ & $-0.000(-0.13)$ & $0.002(1.32)$ \\
\hline BIND & $-0.010(-0.92)$ & $-0.014 *(-1.66)$ & $0.004(0.48)$ & $-0.002(-0.29)$ \\
\hline CEOD & $0.692 * * *(2.78)$ & $0.429 * *(2.12)$ & $0.314 * * *(2.64)$ & $0.212 *(1.87)$ \\
\hline Observations & 741 & 741 & 741 & 741 \\
\hline \# Firms & 330 & 330 & 330 & 330 \\
\hline $\mathrm{AR}(2)$ & 0.68 & 0.27 & 0.31 & 0.14 \\
\hline Hansen & 0.17 & 0.19 & 0.22 & 0.17 \\
\hline
\end{tabular}

System-GMM regressions. Robust $t$-statistics in parentheses

*** $p<0.01$, ** $p<0.05$, * $p<0.1$. See Table 1 for variable definitions

Hypothesis 5, the percentage of institutional investors' shareholding does not influence the level of debt.

Contrary to Hypothesis 3, the finding that ownership concentration has a negative and significant influence on the debt ratio appears surprising. We expected that concentrated ownership provides large controlling shareholders with the ability to place more resources at their disposal without diluting their control over the firm to enable tunneling as documented in recent studies by Liu and Tian (2012) and Lin et al. (2012). However, our results show that this is not the case for GEM firms, which are different from the main board listed firms given that their founders maintain significant shareholdings. This suggests that to the extent that information asymmetry exists between managers and shareholders, ownership concentration facilitates active monitoring and mitigates dilution of their ownership control, thereby limiting managerial self-interest (Lins 2003; Jiang et al. 2010). ${ }^{5}$ In line with Hypothesis 4, our findings demonstrate that the proportion of tradable A-shares influences the ability of SMEs on the GEM to access external sources of debt. This suggests that the equity market reforms put in place since 2005 to transform

\footnotetext{
${ }^{5}$ We also test ownership concentration excluding the controlling shareholder and find similar results.
}

the Chinese stock market into a market that allocates resources efficiently and strengthens corporate governance have been successful. The reforms have enhanced the ability of SMEs to access external debt through enlarging and diversifying their shareholder base. In turn, the resultant risk sharing and transparency in firms' asset valuations influence lenders' willingness to provide debt to SMEs (Li et al. 2011). Finally, contrary to Hypothesis 5, we do not find evidence that the presence of institutional investors influences GEM firms' use of debt. This may indicate that institutional investors' monitoring is generally weak and professional investors do not enhance GEM firms' capacity to take on additional debt.

More generally, our findings are supportive of recent work, which suggests that it is important to understand how the institutional context in which SMEs operate, particularly corporate governance, influences their ability to access external sources of debt (La Rocca et al. 2010; Köksal and Orman 2015). Regarding the more traditional factors, especially tax and operating cash flows, our results in Tables 3 and 4 illustrate that they have no influence on the debt levels among GEM firms. Table 5 further indicates that operating cash flows appear to influence the choice between long-term versus short-term debt usage conditional on the level of debt that is endogenously 


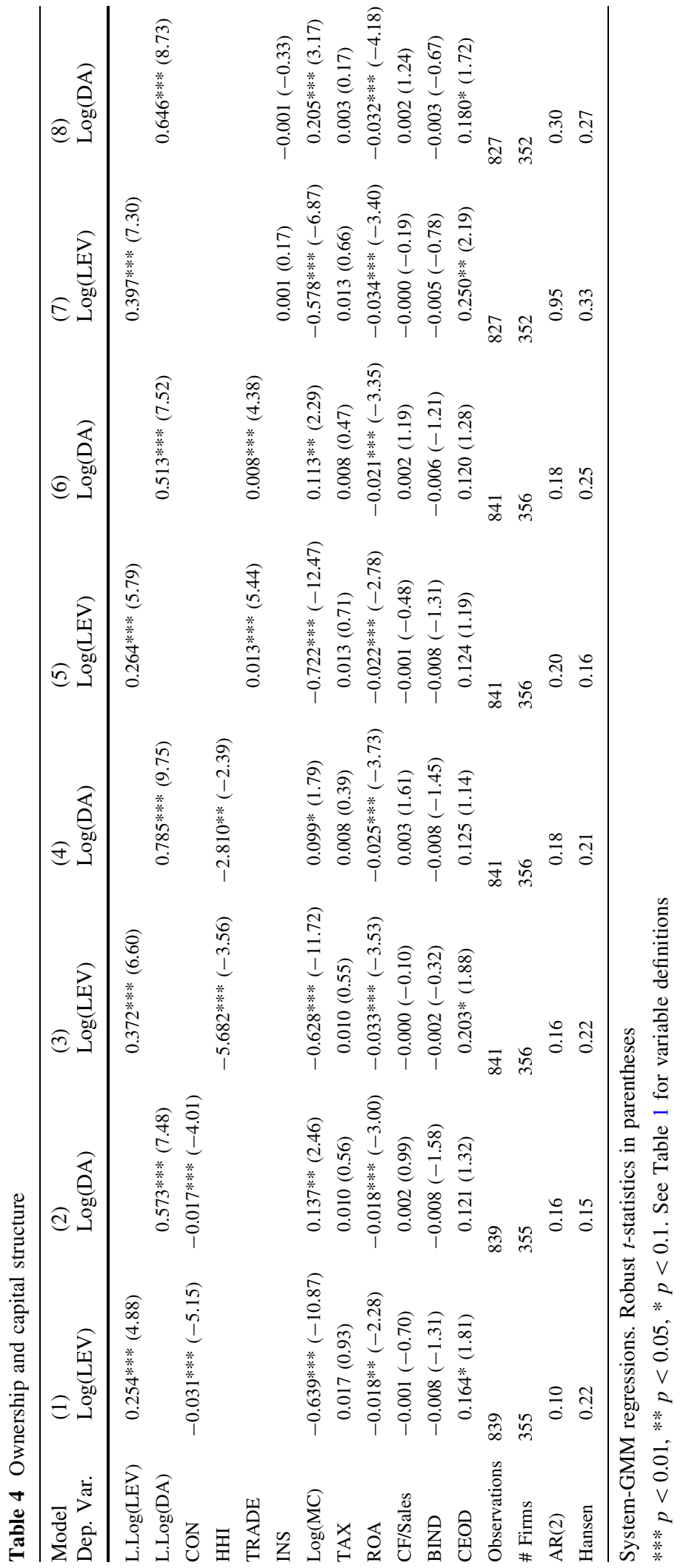


Table 5 Full-model robustness tests

\begin{tabular}{lcc}
\hline Model & $(1)$ & $(2)$ \\
Dep. Var. & $\log (\mathrm{LEV})$ & $\log (\mathrm{DA})$ \\
\hline L.Log(LEV) & $0.108(1.55)$ & $0.394 * * *(3.41)$ \\
L.Log(DA) & & $0.128 * * *(2.71)$ \\
Log(EXSH) & $0.235^{* * *}(3.24)$ & $0.247(1.07)$ \\
EX.Log(EXP) & $0.688^{* * *(2.61)}$ & $-0.012^{* *}(-2.49)$ \\
CON & $-0.017 * *(-2.52)$ & $-0.000(-0.15)$ \\
TRADE & $0.004 * *(1.99)$ & $0.007(1.60)$ \\
INS & $0.004(0.69)$ & $0.160 * *(2.18)$ \\
Log(MC) & $-0.584 * *(-6.63)$ & $0.005(0.29)$ \\
TAX & $-0.006(-0.28)$ & $-0.017 * *(-2.19)$ \\
ROA & $-0.008(-0.65)$ & $0.003(1.47)$ \\
CF/Sales & $-0.003(-1.13)$ & $0.001(0.16)$ \\
BIND & $-0.001(-0.06)$ & $0.335 * *(2.33)$ \\
CEOD & $0.530^{* * *(3.16)}$ & 727 \\
Observations & 727 & 326 \\
\# Firms & 326 & 0.22 \\
AR(2) & 0.27 & 0.26 \\
Hansen & 0.17 & \\
\hline System-GMM & & \\
\hline
\end{tabular}

System-GMM regressions. Robust t-statistics in parentheses *** $p<0.01, * * p<0.05$, * $p<0.1$. See Table 1 for variable definitions

determined. Tax remains an insignificant factor in all models. This can be potentially attributed to on average low profitability of growth firms due to high investment (the average return on assets is just over $8 \%$ ). The benefit of tax shields can only be utilized when firms are making sufficient pretax profit. In addition, statistically speaking, the majority of firms pay a $15 \%$ marginal corporate tax rate (the mean tax rate is $15.04 \%$ ), which is the preferential tax rate for small and high-tech enterprises in China according to its tax regulations. The insignificant influence of tax rate on capital structure is partially expected given almost no variation in the tax rate for our sample.

\subsection{Robustness tests}

The analysis so far has looked at the influence of ownership and governance variables separately in regression models to avoid potential multicollinearity problems due to relationships among these variables (see Huang and Wright 2015). In order to provide greater insight, we use the "horserace" approach to determine the relative importance of the competing influences from different independent variables. The

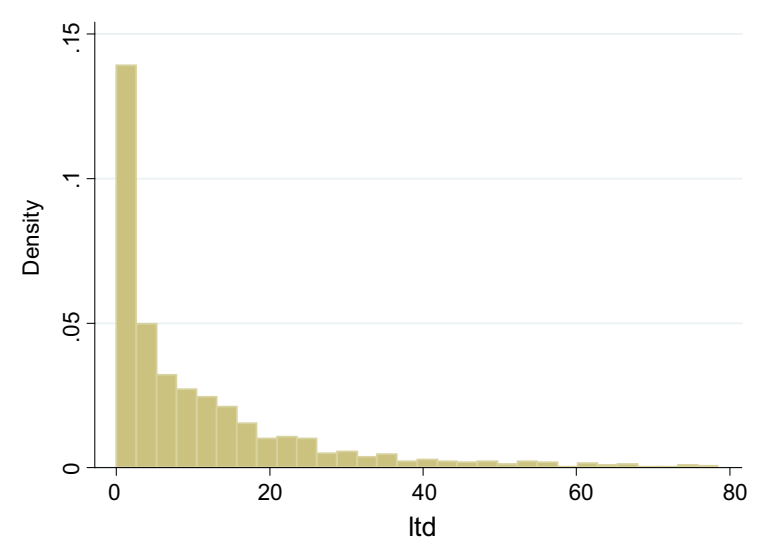

Fig. 3 The percentage of long-term debt in total debt

full-model specification is reported in Table 5 models 1 and 2 . We note that our findings are unaffected, yet the t-statistics and coefficients are relatively smaller compared to results in Tables 3 and 4 due to multicollinearity. The key finding here is that the variables capturing managerial shareholding and incentives are relatively stronger predictors of leverage than ownership structure variables.

Prior studies indicate that SMEs are particularly constrained in access to long-term debt financing, which exposes the borrowing firm to potential rollover difficulties and interest rate fluctuations that arise from the use of short-term debt (Köksal and Orman 2015). We define long-term debt as that which has maturity of over a year and short-term debt as that which has maturity of less than 1 year. Figure 3 shows that the debt utilized by GEM firms in our sample is mostly short term. This is in line with the international evidence documented by Demirgüç-Kunt and Maksimovic (1999) that the majority of debt in developing economies is short-term debt.

We conduct further analysis on firm choice of longterm debt versus short-term debt conditional to the determined level of total debt in Table 6 by adopting random-effects Tobit regressions given the distribution of the long-term debt ratio. The dependent variable LTD in Table 6 denotes the percentage of long-term debt as a proportion of total debt. Considering the level of financial leverage is an endogenous decision, we control for the lagged leverage ratios in our models. Our results suggest that irrespective of the market value- or book value-based leverage ratios, the use of long-term debt at given level of financial leverage is negatively related to ownership 
Table 6 Determinants of the long-term debt percentage

\begin{tabular}{llc}
\hline Models & \multicolumn{1}{l}{$(1)$} & $(2)$ \\
Dep. Var. & LTD & LTD \\
\hline L.log(LEV) & $0.609(1.03)$ & $0.913(1.13)$ \\
L.log(DA) & & $0.029(0.08)$ \\
Log(EXSH) & $0.045(0.12)$ & $0.174(0.13)$ \\
EX.Log(EXP) & $0.186(0.14)$ & $-0.185^{* * *}(-2.63)$ \\
CON & $-0.184 * * *(-2.61)$ & $0.026(0.86)$ \\
INS & $0.026(0.87)$ & $1.409(1.12)$ \\
Log(MC) & $1.486(1.18)$ & $-0.252(-1.17)$ \\
TAX & $-0.245(-1.14)$ & $-0.124(-0.97)$ \\
ROA & $-0.117(-0.91)$ & $0.087 * * *(2.88)$ \\
CF/Sales & $0.085^{* * *(2.82)}$ & $-0.064(-0.57)$ \\
BIND & $-0.061(-0.55)$ & $-3.223^{* *}(-2.37)$ \\
CEOD & $-3.166^{* *}(-2.33)$ & 727 \\
Observations & 727 & 326 \\
\# Firms & 326 & \\
\hline
\end{tabular}

Random-effects Tobit regressions. The dependent variable is LTD, the percentage of long-term debt in total debt. Coefficients on year dummies are omitted. z-statistics in parentheses

$* * * p<0.01, * * p<0.05$, * $p<0.1$. See Table 1 for variable definitions

concentration. This further supports the agency theory view of debt financing. We also note that CEO duality and cash flow-to-sales ratio matters to firms choices between short-term and long-term debt. Other factors in our model do not appear to be statistically significant.

\section{Policy implications}

Our findings have important practical implications for senior managers and policy implications for policy makers. First, from a managerial standpoint, our findings that managerial shareholding and cash compensation are positively related to leverage imply that incentive schemes designed to align the interest of managers to that of the shareholders are effective in increasing the leverage of SMEs on the GEM. In order to improve access external debt, managers might consider increasing the use of such incentives. Second, the negative relationship found between ownership concentration and leverage implies that dominant shareholders perform an efficient internal monitoring role in GEM firms to protect their equity stakes and control from being diluted. Ownership concentration appears to be an important monitoring mechanism in an environment of weak legal protection. Third, institutional investors in China appear to have no influence on the adoption of leverage policies of the GEM firms, which suggests that they play no active monitoring role. This is contrary to the results documented in advanced market economies, which indicate that institutional investors are efficient monitors of corporate performance (Yuan et al. 2008). These results suggest that policy makers should provide additional support and training for institutional investors, to ensure that they play more of an active role in monitoring management. Fourth, our finding that the proportion of tradeable shares improves access to external debt implies that the tradability of shares has improved asset valuation of SMEs and reduced the information asymmetry between borrowers and lenders, thereby facilitating better leverage decisions by the lenders. In order to improve access to external debt for SMEs, policy makers might consider introducing regulations requiring firms listed on the GEM Board to further reduce the ratio of non-tradeable shares to tradable shares. Finally, our findings have important policy implications in light of falling economic growth in China, and the volatility experienced by the Chinese stock market in 2015. Such events highlight the need to improve the corporate governance of SMEs in order to facilitate their ability to access external debt from increasingly risk-averse lenders. As highlighted above, this may be done by strengthening the role played by institutional investors and increasing the number of tradeable shares.

Despite the study's significant contribution, it is important to point out a number of limitations. First, as our study only utilized data from Chinese growth enterprises, we are unable to confirm whether our findings are generalizable to other emerging markets where the institutional environment may be different from that in China. Future research may investigate whether the corporate governance mechanisms operationalized in the present study also improve firms' access to debt in other emerging economies. Second, due to data limitations, it was difficult to establish the differential effects of corporate governance mechanisms on improving access to debt raised from banks versus the corporate bond market. Future research may seek to do this. Third, this study attempted to identify the influence of different governance variables on 
SMEs' leverage decisions, and failed to explicitly investigate whether debt has beneficial impact on SMEs performance. Future research might investigate whether corporate governance mechanisms differentially influence the access to different sources of debt and whether such access to debt has a resultant influence on the performance of SMEs.

\section{Conclusion}

Utilizing data from publicly traded SMEs on the Chinese Growth Enterprises Market, this paper examined how the corporate governance mechanisms adopted by SMEs influence their financing decisions. Our sample firms are mostly high-growth, technologyintensive, and more "entrepreneurial"-type SMEs that have successfully made their IPOs since the establishment of the second board stock market in China in 2009. We found that the financial leverage of GEM firms is positively influenced by executives' share- holding and cash compensation. Ownership concentration appears to reduce leverage, whereas the percentage of tradable shares increases leverage. Institutional investors' shareholding does not influence the level of debt. Traditional factors such as tax and operating cash flow were found to be insignificant in explaining the debt levels of GEM firms, highlighting the importance to consider corporate governance as an important antecedent of capital structure.

Open Access This article is distributed under the terms of the Creative Commons Attribution 4.0 International License (http:// creativecommons.org/licenses/by/4.0/), which permits unrestricted use, distribution, and reproduction in any medium, provided you give appropriate credit to the original author(s) and the source, provide a link to the Creative Commons license, and indicate if changes were made.

\section{Appendix}

See Table 7.

Table 7 Measurement of dependent and independent variables

\begin{tabular}{|c|c|c|c|}
\hline Variables & Measures & Sign & Theoretical justification \\
\hline LEV & $\begin{array}{l}\text { Market value-based debt ratio, } \mathrm{LEV}=\text { book value of debt } / \\
\text { (market capitalization }+ \text { book value of debt) }\end{array}$ & & \\
\hline DA & Book value-based debt-to-assets ratio & & \\
\hline LTD & The percentage of long-term debt & & \\
\hline CEOD & CEO duality dummy. $\mathrm{CEO}$ as chair $=1$; otherwise $=0$ & + & Agency theory \\
\hline $\mathrm{CON}$ & The total percentage of shares held by top 10 shareholders & \pm & Agency theory \\
\hline $\log (\mathrm{EXSH})$ & $\begin{array}{l}\text { The total of executives' shareholding number. We use log } \\
\text { transformation to winsorize the data. }\end{array}$ & + & Agency theory \\
\hline EX.Log(EXP) & $\begin{array}{l}\text { Size- and industry-adjusted cash compensation for the top } 3 \\
\text { executives. Defined as the excessive cash compensation. We } \\
\text { use log transformation to winsorize the data. }\end{array}$ & + & Agency theory \\
\hline TRADE & The percentage of tradable shares in total number of shares & + & Pecking order/tradeoff \\
\hline INS & The percentage shareholding by institutional investors & + & Tradeoff/agency theory \\
\hline ROA & Return-on-assets ratio & - & Pecking order/tradeoff \\
\hline Tax & The corporate tax rate & + & Tradeoff \\
\hline BIND & The percentage of board members who are independent & - & Agency theory \\
\hline $\mathrm{CF} / \mathrm{Sales}$ & The operating cash flows-to-sales ratio & - & Pecking order/tradeoff \\
\hline $\log (\mathrm{MC})$ & The log of market capitalization (MC). & - & Pecking order/tradeoff \\
\hline
\end{tabular}




\section{References}

Ajinya, B., Bhojraj, S., \& Sengupta, P. (2005). The association between outside directors, institutional investors and the properties of management earnings forecasts. Journal of Accounting Research, 43, 343-376.

Antoniou, A., Guney, Y., \& Paudyal, K. (2008). Determinants of capital structure: Capital market oriented versus bank oriented institutions. Journal of Financial and Quantitative Analysis, 43(2), 59-92.

Arellano, M., \& Bover, O. (1995). Another look at the instrumental variable estimation of error-components models. Journal of Econometrics, 68, 29-51.

Beck, T., \& Demirguc-Kunt, A. (2006). Small and medium-size enterprises: Access to finance as a growth constraint. Journal of Banking \& Finance, 30(11), 2931-2943.

Beck, T., Demirguc-Kunt, A., \& Maksimovic, V. (2008). Financing patterns around the world: Are small firms different? Journal of Financial Economics, 89, 467-487.

Berger, P., Ofek, E., \& Yermarck, D. (1997). Managerial entrenchment and capital structure decisions. Journal of Finance, 52(4), 1411-1438.

Berger, A. N., \& Udell, G. F. (1998). The economies of small business finance: The roles of private equity and debt markets in the financial growth cycle. Journal of Banking \& Finance, 22(6-8), 873-897.

Berger, A. N., \& Udell, G. F. (2006). A more complete conceptual framework for SME finance. Journal of Banking \& Finance, 30(11), 2945-2966.

Bhojraj, S., \& Sengupta, P. (2003). Effect of corporate governance on bond ratings and yields: The role of institutional investors and the outside directors. The Journal of Business, 76, 455-475.

Blundell, R., \& Bond, S. (1998). Initial conditions and moment restrictions in dynamic panel data models. Journal of Econometrics, 87, 115-143.

Chen, J. (2004). Determinants of capital structure of Chineselisted companies. Journal of Business Research, 57(12), 1341-1351.

Chen, J., Ezzamel, M., \& Cai, Z. (2011). Managerial power theory, tournament theory, and executive pay in China. Journal of Corporate Finance, 17(4), 1176-1199.

Chen, G., Firth, M., \& Xu, L. (2009). Does the type of ownership control matter? Evidence from China's listed companies. Journal of Banking \& Finance, 33, 171-181.

Chuang, W., \& Lee, B. (2011). The informational role of institutional investors and financial analysts in the market. Journal of Financial Markets, 14(3), 465-493.

Chung, H., Judge, W. Q., \& Li, Y. H. (2015). Voluntary disclosure, excess executive compensation and firm value. Journal of Corporate Finance, 32, 64-90.

Claessens, S., Djankov, S., Fan, J., \& Lang, H. P. (2002). Disentangling the incentive and entrenchment effects of large shareholdings. Journal of Finance, 57, 27412771.

Coles, J. L., Daniel, N. D., \& Naveen, L. (2006). Managerial incentives and risk-taking. Journal of Financial Economics, 79, 431-468.

Dasilas, A., \& Papasyriopoulos, N. (2015). Corporate governance, credit rating and the capital structure of Greek SME and large listed firms. Small Business Economics, 45, 215-244.

Demirgüç-Kunt, A., \& Maksimovic, V. (1999). Institutions, financial markets, and firm debt maturity. Journal of Financial Economics, 54(3), 295-336.

Ding, Y., Nowak, E., \& Zhang, H. (2010). Foreign vs. domestic listing: An entrepreneurial decision. Journal of Business Venturing, 25(2), 175-191.

Du, J., Guariglia, A., \& Newman, A. (2015). Do social capital building strategies influence the financing behavior of Chinese private small and medium-sized enterprises? Entrepreneurship, Theory \& Practice, 39(3), 601-631.

Elston, J. A., Chen, S., \& Weidinger, A. (2016). The role of informal capital on new venture formation and growth in China. Small Business Economics, 46, 79-91.

Faccio, M., Lang, H. P., \& Young, L. (2010). Pyramiding vs leverage in corporate groups: international evidence. Journal of International Business Studies, 41, 88-104.

Fama, E. (1980). Agency problems and the theory of the firm. Journal of Political Economy, 88, 288-307.

Finkelstein, S. (1992). Power in top management teams: Dimensions, measurement, and validation. Academy of Management Journal, 35(3), 505-538.

Firth, M., Lin, C., Liu, P., \& Wong, S. (2009). Inside the black box: Bank credit allocation in China's private sector. Journal of Banking \& Finance, 33, 1144-1155.

Firth, M., Lin, C., \& Zou, H. (2010). Friend or foe? The role of state and mutual fund ownership in the split share structure reform in China. Journal of Financial and Quantitative Analysis, 45(3), 685-706.

Gompers, P., Ishii, J., \& Metrick, A. (2003). Corporate governance and equity prices. Quarterly Journal of Economics, 118, 107-155.

Guney, Y., Li, L., \& Fairchild, R. (2011). The relationship between product market competition and capital structure in Chinese listed firms. International Review of Financial Analysis, 20(1), 41-51.

Hambrick, D. C., \& Mason, P. (1984). Under echelons: The organization as a reflection of its top managers. Academy of Management Review, 9, 193-206.

Haque, F., Arun, T., \& Kirkpatrick, C. (2011). Corporate governance and capital structure in developing countries: A case study of Bangladesh. Applied Economics, 43(6), 673-681.

Harris, M., \& Raviv, A. (1988). Corporate control contests and capital structure. Journal of Financial Economics, 20, 203-236.

Huang, G., \& Song, F. M. (2006). The determinants of capital structure: Evidence from China. China Economic Review, 17(1), 14-36.

Huang, W., \& Wright, B. (2015). Analyst earnings forecast under complex corporate ownership in China. Journal of International Financial Markets, Institutions and Money, 35, 69-84.

Hui, C. H., Lo, C. F., \& Huang, M. X. (2006). Are corporates' target leverage ratios time-dependent? International Review of Financial Analysis, 15(3), 220-236.

Jensen, M. (1986). Agency costs of free cash flow, corporate finance, and takeovers. American Economic Review, 76(2), 323-339. 
Jensen, M., \& Meckling, W. H. (1976). Theory of the firms: Managerial behavior, agency costs and ownership structure. Journal of Financial Economics, 3(4), 305-360.

Jiang, G., Lee, C., \& Yue, H. (2010). Tunneling through intercorporate loans: The China experience. Journal of Financial Economics, 98, 1-20.

Kim, W. S., \& Sorensen, E. H. (2006). Evidence of the agency costs of debt on corporate debt policy. Journal of Financial and Quantitative Analysis, 21(2), 131-144.

Köksal, B., \& Orman, C. (2015). Determinants of capital structure: Evidence from a major developing economy. Small Business Economics, 44, 255-282.

La Porta, R., Lopez-De-Silanes, F., \& Shleifer, A. (1999). Corporate ownership around the world. Journal of Finance, 54, 471-517.

La Rocca, M., La Rocca, T., \& Cariola, A. (2010). The influence of local institutional differences on the capital structure of SMEs: Evidence from Italy. International Small Business Journal, 28(3), 234-257.

Lee, B., Rui, O. M., \& Wang, S. S. (2004). Information transmission between the NASDAQ and Asian second board markets. Journal of Banking \& Finance, 28(7), 1637-1670.

Li, K., Wang, T., Cheung, Y., \& Jiang, P. (2011). Privatization and risk sharing: Evidence from the split share structure reform in China. The Review of Financial Studies, 24(7), 2499-2525.

Li, K., Yue, H., \& Zhao, L. (2009). Ownership, institutions, and capital structure: Evidence from China. Journal of Comparative Economics, 37(3), 471-490.

Lin, C., Ma, Y., Malatesta, P., \& Xuan, Y. (2012). Corporate ownership structure and bank loan syndicate structure. Journal of Financial Economics, 104, 1-22.

Lins, K. V. (2003). Equity ownership and firm value in emerging markets. Journal of Financial and Quantitative Analysis, $38,159-184$.

Liu, Y., \& Jiraporn, P. (2010). The impact of CEO power on bond ratings and yields. Journal of Empirical Finance, 17, 744-762.

Liu, Q., \& Tian, G. (2012). Controlling shareholder, expropriations and firm's leverage decision: Evidence from
Chinese Non-tradable share reform. Journal of Corporate Finance, 18, 782-803.

Myers, S. C., \& Majluf, N. S. (1984). Corporate financing and investment decisions when firms have information that investors do not have. Journal of Financial Economics, 13(2), 187-222.

Newman, A., Gunessee, S., \& Hilton, B. (2012). Applicability of financial theories of capital structure to the Chinese cultural context: A study of privately owned SMEs. International Small Business Journal, 30(1), 65-83.

Nofsinger, J. R., \& Wang, W. (2011). Determinants of start-up firm external financing worldwide. Journal of Banking \& Finance, 35, 2282-2294.

Qian, M., \& Yeung, B. Y. (2015). Bank financing and corporate governance. Journal of Corporate Finance, 32, 258-270.

Shleifer, A., \& Vishny, R. (1989). Management entrenchment: The case of manager-specific investments. Journal of Financial Economics, 25, 123-139.

Stulz, R. (1990). Managerial discretion and optimal financing policies. Journal of Financial Economics, 26, 3-28.

Watson, J. (2006). External funding and firm growth: Comparing female-and male-controlled SMEs. Venture Capital, 8(1), 33-49.

Wen, Y., Rwegasira, K., \& Bilderbeek, J. (2002). Corporate governance and capital structure decisions of the Chinese listed firms. Corporate Governance: An International Review, 10(2), 75-83.

Windmeijer, F. (2005). A finite sample correction for the variance of linear efficient two-step GMM estimators. Journal of Econometrics, 126, 25-51.

Wintoki, M., Linck, J., \& Netter, J. (2012). Endogeneity and the dynamics of internal corporate governance. Journal of Financial Economics, 105(3), 581-606.

Yuan, R., Xiao, J. Z., Milonas, N., \& Zou, J. H. (2009). The role of financial institutions in the corporate governance of listed Chinese companies. British Journal of Management, 20(4), 562-580.

Yuan, R., Xiao, J. Z., \& Zou, H. (2008). Mutual funds' ownership and firm performance: Evidence from China. Journal of Banking \& Finance, 32(8), 1552-1565. 